\title{
Urgensi Habituasi Nilai Karakter Kemandirian Dan Tanggung Jawab Peserta Didik Sekolah Menengah Keguruan
}

\author{
Puji Lestari ${ }^{1 *}$, Aldi Setiawan ${ }^{1}$, Anggriyani Puspitaningrum ${ }^{1}$
}

${ }^{1}$ Universitas Negeri Semarang, Semarang

\section{A R T I C L E I N F O}

Article history:

Received 31 Oktober 2018

Accepted 30 November

2018

Available online 31

Desember 2018

Kata Kunci:

Habituasi; Karakter;

Kemandirian;

Tanggungjawab

Keywords:

Habituation; Character

Independence; Responsible

\begin{abstract}
A B S T R A K
Penanaman dan penguatan karakter kemandirian dan tanggung jawab sangat penting bagi peserta didik Sekolah Menengah Kejuruan (SMK) mengingat peran SMK menghadapi tantangan di dunia kerja dengan tuntutan kebutuhan pembinaan sumber daya manusia yang berkualitas. Oleh karenanya, habituasi nilai karakter kemandirian dan tanggungjawab harus dilakukan. Penelitian kualitatif ini dilaksanakan di SMKN 5 Semarang dan SMKN 2 Salatiga, menggali penanaman dan penguatan karakter kemandirian dan tanggungjawab melalui wawancara, observasi dan data dari dokumen. Hasil penelitian menunjukkan; bahwa habituasi nilai karakter kemandirian dan tanggungjawab dilakukan melalui dua bentuk kegiatan, yakni melalui pelajaran PPKn dan melalui kegiatan diluar pembelajaran yang saling terintegrasi. Banyaknya mata pelajaran praktik selama ini, muncul persepsi bahwa mata pelajaran PPKn tidak dianggap sebagai mata pelajaran yang penting di SMK. PPKn menjadi mata pelajaran yang menanamkan karakter bagi peserta didik di SMK selain mata
\end{abstract} pelajaran lainnya. Penilaian karanter kemandirian dan tanggungjawab pada mata pelajaran PPKn diintegrasikan dengan mata pelajaran lainnya, misalnya ketika siswa melaksanakan kegiatan praktik dengan menggunakan "Kartu Kendali Individu". Dengan demikian, karakter kemandirian dan tanggungjawab dapat merembes ke dalam aktifitas peserta didik SMK melalui kegiatan di luar jam kelas.

\section{A B S T R A C T}

Planting and strengthening the character of independence and responsibility are very important for Vocational High School (SMK) students considering the role of Vocational Schools in facing challenges in the world of work with the demand for quality human resources development. Therefore, habituation of the character values of independence and responsibility must be carried out. This qualitative research was carried out at Vocational High School 5 Semarang and SMKN 2 Salatiga, explored the planting and strengthening of the character of independence and responsibility through interviews, observation, and data from documents. The results of the study show; that habituation of character values of independence and responsibility is carried out through two forms of activities, namely through PPKn lessons and through activities outside of mutual integrated learning. The number of practical subjects so far, there is a perception that PPKn subjects are not considered as important subjects in Vocational Schools. PPKn is a subject that instills character for students in vocational schools other than other subjects. The quarantine assessment of independence and responsibility for PPKn subjects is integrated with other subjects, for example when students carry out practical activities using "Individual Control Cards". Thus, the character of independence and responsibility can seep into the activities of vocational students through activities outside of class hours. 


\section{Pendahuluan}

Tingginya angka pengangguran di Indonesia, sampai saat ini masih menjadi persoalan ketenagakerjaan. Pemberdayaan angkatan kerja muda untuk meningkatkan kompetensi generasi muda yang dapat bersaing di dunia kerja atau bahkan membuka lapangan pekerjaan sendiri, diharapkan hadir mengatasi masalah tersebut. Pemberdayaan ini dapat dilakukan melalui pendidikan, sebagai investasi pembangunan sumber daya manusia. Usaha sadar dan terencana untuk mewujudkan suasana belajar dan proses pembelajaran agar peserta didik secara aktif mengembangkan potensi dirinya untuk memiliki kekuatan spiritual keagamaan, pengendalian diri, kepribadian, kecerdasan, akhlak mulia, serta keterampilan yang diperlukan dirinya, masyarakat, bangsa dan negara (UU No. 20 Tahun 2003 tentang Sistem Pendidikan Nasional).

Sekolah Menengah Kejuruan (SMK), satuan pendidikan yang mencetak tenaga kerja muda yang bermutu, unggul merata, terampil, berkarakter dan berdaya saing dalam dunia kerja. Keberadaannya diperlukan mengatasi tantangan ketenagakerjaan atau di dunia kerja, sebagaimana menjadi visi dari Direktorat Pembinaan SMK Direktorat Jenderal Pendidikan Dasar dan Menengah Kementerian Pendidikan dan Kebudayaan Republik Indonesia. Peran SMK menghadapi tantangan di dunia kerja ke depan menjadi semakin penting karena tuntutan kebutuhan pembinaan sumber daya manusia yang berkualitas. Lebih lanjut, outcome dari pembinaan ini menentukan kemampuan suatu negara dalam menghadapi persaingan antar negara maupun perdagangan bebas. Karakteristik khusus dari SMK dibandingkan dengan satuan pendidikan lain adalah karena SMK memang merupakan satuan pendidikan kejuruan yang punya ciri-ciri sebagai berikut: (1) Pendidikan kejuruan diarahkan untuk mempersiapkan peserta didik memasuki lapangan kerja, (2) didasarkan atas "demand-driven" (kebutuhan dunia kerja), (3) ditekankan pada penguasaan pengetahuan, keterampilan, sikap dan nilai-nilai yang dibutuhkan oleh dunia kerja,.. dan sebagainya (Djojonegoro, 1998:38). Oleh karenanya, dalam menghadapi tantangan zaman untuk memasuki dunia kerja, lulusan SMK harus memiliki karakter mandiri dan tanggung jawab.

Karakter kemandirian dan tanggungjawab dibutuhkan dalam lingkungan SMK disamping nilai karakter lainnya, dikarenakan SMK memiliki karakteristik khusus, lulusannya harus siap untuk langsung terjun ke dunia kerja. Peserta didik SMK dibiasakan lebih mandiri dan bertanggung jawab, dimaksudkan agar para peserta didik siap terhadap peralihan dari masa sekolah ke masa kerja. Yang mana di dunia kerja tentu lebih besar tekanan dan tuntutannya dibandingkan saat masih bersekolah. Apalagi sekarang ini adalah era globalisasi yang menjadikan persaingan di dunia kerja menjadi semakin ketat. Tuntutan-tuntutan di dunia kerja membuat kompetensi dan integritas setiap orang harus mumpuni. Haryanto (2011:42-43) bahwa karakter merupakan sikap dan kebiasaan seseorang yang memungkinkan dan mempermudah tindakan moral. Urgensi pengembangan karakter bangsa saat ini, dilandasi beberapa pemikiran, salah satunya bahwa, pembangunan karakter bangsa merupakan sebuah kebutuhan asasi dalam proses berbangsa karena hanya bangsa yang memiliki karakter dan jati diri yang kuat yang akan eksis ((Desain Induk Pembangunan Karakter Bangsa Tahun 20102025:1).

Karakter kemandirian dan tanggungjawab harus menjadi habituasi bagi pesera didik di SMK. Habituasi adalah proses yang terjadi ketika nilai-nilai sosial dihayati oleh manusia, tercipta melalui proses sosialisasi nilai-nilai yang berlangsung lama, mengendap menjadi cara berfikir dan pola perilaku yang kemudian menetap pada diri manusia itu (Jenkins, 1992:55). Kemudian habitus berlangsung dengan cara tahan lama, sistematis dan non mekanis (Hidrawati, 2017:6). Habituasi nilai karakter tanggungjawab dan kemandirian menjadi penting bagi siswa SMK untuk mempersiapkan mereka terjun dalam masyarakat. sikap kemandirian itu tidak mudah bergantung pada orang lain dalam memenuhi kebutuhannya atau mengatasi persoalannya terutama di lingkungan pendidikan. Menarik mengkaji hal tersebut, karena kenyataannya dalam proses pendidikan di sekolah yang tidak demokratis dan cenderung memberikan indoktrinasi tanpa argumentasi kepada peserta didik, akan menghambat kemandirian mereka. Demikian juga proses pendidikan yang menekankan pentingnya pemberian sanksi atau hukuman juga dapat menghambat perkembangan kemandirian peserta didik. Sebaliknya, proses pendidikan yang 
lebih menekankan pentingnya penghargaan terhadap potensi anak, pemberian reward, dan penciptaan kompetisi positif akan memperlancar kemandirian anak.

Banyak penelitian, mengenai penanaman, penguatan dan habituasi nilai karakter di sekolah, misalnya Wuryadani (2016) meneliti implementasi pendidikan karakter kemandirian di Muhammadiyah Boarding School. Asep Dahliyana (2017), mengkaji mengenai penguatan pendidikan karakter melalui kegiatan ekstrakurikuler di sekolah. Tirtoni (2016) menulis buku tentang inovasi melalui strategi habituasi dan program kegiatan sekolah berkarakter. Namun, dari banyaknya riset, kajian mengenai habituasi nilai karakter di SMK dan urgensinya belum dilaksanakan. Riset mengenai habituasi nilai karakter kemandirian dan tanggungjawab di SMK, melihat nilai-nilai karakter ini masuk dalam masing-masing individu, merembes (dirembeskan) melalui proses pembelajaran yakni sebagai capaian pembelajaran dan dalam kegiatan di luar pembelajaran.

\section{Metode}

Penelitian ini adalah penelitian kualitatif deskriptif. Menggali fenomena yang terjadi pada proses penanaman dan penguatan karakter peserta didik SMK melalui habituasi. Data diambil di dua SMK yakni pada SMK N 5 Kota Semarang dan SMK N 2 Salatiga, dengan wawancara mendalam pada Pengelola Sekolah (Kepala Sekolah, guru) dan peserta didik di dua SMK. Selain itu, data diperoleh melalui observasi (pengamatan secara langsung) terhadap kegiatan-kegiatan yang menjadi proses semaian nilai-nilai karakter kemandirian dan tanggungjawab kepada peserta didik sehingga menjadi habituasi mereka dalam keseharian di lingkungan sekolah dan juga dokumen-dokumen yang memberi catatan mengenai bagaimana nilai karakter tersebut ditanamkan dan dikuatkan di lingkungan sekolah.

\section{Hasil dan pembahasan}

Penanaman dan penguatan karakter kemandirian dan tanggung jawab di SMK Negeri 5 Semarang dan SMK Negeri 2 Salatiga, secara garis besar laksanakan dalam dua bentuk kegiatan yakni di dalam kegiatan pembelajaran dan pada kegiatan non pembelajaran yang dilaksanakan secara terintegrasi. Kegiatan perencanaan, pelaksanaan kegiatan dan evaluasi dilaksanakan. Kegiatan perencanaan dilakukan dengan mengembangkan perangkat karakter yang akan digali, dikristalisasi dan dirumuskan. Tahapan pelaksanaan yakni implementasi kegiatan dengan mengembangkan pengalaman dan proses belajar yang bermuara pada pembentukan dan penguatan karakter. Sedangkan pada tahap evaluasi hasil dilaksanakan assesmen program untuk perbaikan berkelanjutan yang dirancang dan dilaksanakan untuk pembudayaan karakter yang dipilih.

Kegiatan pembelajaran yang dimaksud adalah meliputi tahap perencanaan pembelajaran, pelaksanaan pembelajaran, dan penilaian, pada semua mata pelajaran terutama pada pembelajaran PPKn. Kegiatan non pembelajaran meliputi kegiatan keterampilan (praktik) melalui pembiasaan. Walaupun ranah penanaman dan penguatan karakter kemandirian ini dibagi menjadi dua, namun pada prinsipnya tetap sama yaitu merespon kemandirian dan tanggung jawab peserta didik untuk meningkatkan kemungkinan berulangnya kembali sifat, perilaku, atau cara berpikir seseorang tersebut yang mencerminkan kemandirian. Cerminan karakter ini dimuat dalam indikator kemandirian pada penelitian ini, yaitu bertanggung jawab, mampu mengatasi masalah tanpa bantuan orang lain, percaya diri, otonomi (menentukan sendiri sikap/perilaku), dan berpikir kritis.

Dalam kegiatan pembelajaran, pada dasarnya semua mata pelajaran yang diajarkan di sekolah termasuk di SMK memuat pendidikan karakter. Mata pelajaran Pendidikan Pancasila dan Kewarganegaraan (PPKn) menjadi tumpuan awal tercapainya kompetensi sikap karakter bertanggungjawab dan mandiri, karena mata pelajaran ini memuat langsung terkait dengan budi pekerti atau akhlak mulia. PPKn secara langsung telah mengenalkan nilai-nilai yang seharusnya dilakukan di kehidupan sehari-hari, sehingga peserta didik berperilaku sesuai dengan apa yang sepantasnya dilakukan.

Selama ini diperoleh data mengenai persepsi tentang mata pelajaran PPKn di SMK seolah merupakan pelajaran yang kurang terespon oleh siswa karena selama ini mereka 
mengedepankan mata pelajaran praktik saja. Berdasarkan hasil wawancara mendalam dengan guru-guru dan peserta didik SMK, keberadaan mata pelajaran PPKn dengan materi dan pencapaian kompetensi yang ada di dalamnya ditempatkan sebagai mata pelajaran yang penting dan terintegrasi dengan mata pelajaran lain untuk membentuk kepribadian dan karakter peserta didik. Yang dimaksud terintegrasi adalah, dalam pembelajaran PPKn, pencapaian kompetensi sikap oleh peserta didik di dua SMK ini tidak hanya dilaksanakan dalam pembelajaran di kelas PPKn saja, melainkan pada saat siswa melaksanakan kegiatan pembelajaran mata pelajaran lainnya terutama pada kegiatan-kegiatan praktik (di laboratorium dan bengkel kerja) dan atau kegiatan lainnya di sekolah.

Pertama, pembiasaan dalam pembelajaran di sekolah. Cara ini dilakukan dengan menanamkan dan menguatkan nilai karakter kemandirian dan tanggung jawab sebagai capaian dalam kegiatan pembelajaran PPKn dan mata pelajaran yang lain melalui perencanaan pembelajaran, pelaksanaan pembelajaran dan evaluasi pembelajaran. Dalam evaluasi inilah, keberhasilan penanaman dan penguatan karakter kemandirian dan tanggungjawab kepada peserta didik di dalam pembelajaran PPKn, dinilai menggunakan pengamatan sikap dalam lembar penilaian sikap secara terintegrasi oleh guru PPKn dan guru mata pelajaran praktik (guru mata pelajaran lainnya). Jika guru mendapati peserta didik yang mandiri atau aspek lainnya, maka guru akan mencatatnya dalam lembar penilaian sikap untuk menambah nilai sikap peserta didik yang bersangkutan. Penilaian ini juga sebagai apresiasi terhadap peserta didik atas kemandiriannya supaya mereka semakin termotivasi untuk mengamalkan sikap/perilaku tanggung jawab dan mandiri yang sudah tertanam.

Guru PPKn aktif berinteraksi dengan guru mata pelajaran lain. Tujuannya adalah agar koordinasi terjalin terintegrasi antara apa yang disampaikan oleh guru PPKn di kelas, dipraktikkan langsung dalam kegiatan pembelajaran yang lain di sekolah, dengan harapan semua guru membimbing peserta didik supaya menjadi lebih mandiri dan bertanggungjawab di sekolah. Teknisnya, masing-masing siwa di sekolah memegang buku kendali yang mencatat aktifitas mereka di jam-jam praktik sekolah baik dalam pembelajaran maupun kerja mandiri yang divalidasi oleh guru mata pelajaran praktik atau kepala laboratorium. Demikian jika masih ada peserta didik yang mendapatkan nilai di bawah KKM, maka guru-guru akan memberikan tugas tambahan atau remedial atau bahkan hukuman yang bersifat membangun kepada peserta didik sebagai cara untuk menambah nilai mereka agar karakter tanggung jawab dan mandiri dapat dilakukan dalam keseharian.

Kedua, pembiasaan dilakukan di luar jam pelajaran sekolah. Berdasarkan observasi pada kegiatan pembelajaran di SMK N 5 Semarang untuk menunjang kemandirian peserta didik; a) sekolah mengijinkan peserta didik untuk menggunakan fasilitas berupa laboratorium komputer jurusan di luar jam sekolah atau setelah pulang sekolah. Bertambahnya durasi praktik mereka secara bebas diharapkan membuat kemampuannya semakin berkembang dan dalam belajar semakin terpancing untuk mandiri dengan indikatornya yaitu otonom. Dalam praktik mandiri ini, masing-masing individu memahami tentang keselamatan diri mereka ketika melaksanakan praktik yang menjadi tugas guru maupun dalam rangka pengembangan dirinya. Mereka akan mengisi "Kartu Kendali Individu" yang berisi lembar kerja dan kemudian meminta validasi dari kepala laboratoriumnya. Peserta didik dilatih untuk bertanggung jawab atas dirinya dan lingkungannya ketika mereka diberi kepercayaan; b) pada Jurusan Teknik Komputer dan Jaringan, ditanamkan sejak dini pada peserta didik bahwa setiap tugas yang diberikan oleh guru harus disusun berdasarkan kemampuan masing-masing siswa. Jika ada yang dalam membuat tugas sama, diketahui mencontek, maka akan diberi sanksi yang berat pada yang bersangkutan. Demikian peserta didik dituntut menjaga kerapian dan kebersihan laboratorium; dengan menata sepatu di rak yang disedikan di luar laboratorium. Para peserta didik di TKJ juga diharuskan berbaris terlebih dahulu sebelum memasuki laboratorium.

Semakin peserta didik disiplin, maka akan semakin siap mereka untuk memasuki dunia kerja atau bermasyarakat. Pendisiplinan peserta didik ini juga sebagai upaya agar mereka menjadi semakin bertanggung jawab dan disiplin yang merupakan salah satu indikator kemandirian dan tanggungjawab. Apa yang bisa dilihat pada proses pengamatan langsung? Peserta didik akan tertib dalam bersikap, berperilaku dalam kegiatan-kegiatan yang mereka 
lakukan di sekolah, walaupun mereka tidak sedang diawasi, ditunggui oleh guru. "Kartu kendali individu" yang berisi catatan kegiatan, sikap, perilaku mereka ini hanya sebagai instrumen peserta didik dapat melaksanakan kegiatan yang menunjukkan pada perilaku mandiri dan bertanggung jawab.

Di SMKN 2 Salatiga penanaman karakter pada peserta didik. Pada tahap perencanaan, capaian karakter termasuk karakter kemandirian dan tanggungjawab diintegrasikan dalam kegiatan di luar jam pelajaran, misalnya melalui penetapan tata tertib sekolah, dan kegiatan lain yang telah dirumuskan oleh STP2K (Satuan Tugas Pelaksana Pembinaan Kesiswaan) untuk mewujudkan habituasi yang baik bagi peserta didik, melalui tata tertib yang berisi aturan dan sanksi jika terjadi pelanggaran, peserta didik secara mandiri dan bertanggungjawab terhadap dirinya sendiri. Pengetahuan mereka mengenai larangan perbuatan dan tingkah laku melanggar di sekolah akan secara otomatis mengarahkan peserta didik melaksanakan, berperilaku yang tidak melanggar. Lebih dari itu, habituasi nilai karakter tanggungjawab dan kemandirian di SMK 2 ini diarahkan untuk mewujudkan kreatifitas peserta didik melalui kegiatan ekstra kurikuler.

Wawancara mendalam dengan subjek penelitian diperoleh informasi bahwa penanaman dan penguatan karakter yang integratif di lingkungan SMK penting dilakukan dengan memahami bahwa aspek-aspek kemandirian dan tanggungjawab pada peserta didik SMK mencakup; kemampuan mereka berinisiatif atau kreatif, beradaptasi dengan lingkungan mereka dengan mengatasi rintangan dalam lingkungannya, mengarahkan perilaku setiap individu untuk memperoleh kepuasan dalam melaksanakan tugas-tugas mereka, dan mengerjakan tugas-tugas rutin oleh dirinya sendiri; menerima resiko-resiko atas apa yang telah ia lakukan dengan kata lain tidak melempar kesalahan yang ia perbuat pada orang lain. Menguatkan kemandirian dan tanggung jawab peserta didik untuk mencapai aspek-aspek itu tidak mudah, tetapi hal itu bisa dilakukan secara bertahap melalui habituasi atau pembiasaan. Yang terpenting peserta didik di SMK harus diberi kesempatan untuk melakukannya. Di lingkungan sekolah, tentu saja habituasi ini tetap dalam pengawasan guru dan sekolah. Penilaian tetap dilakukan untuk mengukur keberhasilan capaian kompetensi sikap.

Ketika seorang peserta didik SMK mampu mencapai kompetensi sikap kemandirian dan tanggung jawab, mereka akan memiliki kemampuan; melakukan interaksi dengan orang lain dan tidak bergantung atau menunggu aksi dari orang lain; mengatasi berbagai masalah yang dihadapi; mengendalikan emosi dan mampu membuat keputusan serta tidak tergantung pada orang tua dan atau orang-orang di sekitarnya; dan sebagainya. Dengan sikap dan perilaku mandiri yang telah merembes ini, setiap individu peserta didik akhirnya tidak merasa dipaksa dalam melaksanakannya dalam kehidupan mereka. Habituasi nilai karakter kemandirian dan tanggungjawab penting dilaksanakan di SMK, mengingat peserta didik nantinya akan langsung diserap dalam dunia kerja.

\section{Simpulan dan saran}

Pembiasaan nilai-nilai karakter kemandirian dan tanggung jawab di SMK dapat diselenggarakan di dalam dan di luar pembelajaran secara integratif. Penanaman dan penguatan karakter kemandirian yang di dalam pembelajaran yaitu PPKn dilaksanakan dari tahap perencanaan, pelaksanaan, dan penilaian. Penilaian dua karakter ini terintegrasi pada pelaksanaan mata pelajaran lainnya, khususnya pada mata pelajaran praktik. Selain itu, kegiatan-kegiatan yang diselenggarakan dalam bentuk ekstrakurikuler, praktik laboratorium di luar jam sekolah juga menjadi sarana penting penanaman karakter kemandirian dan tanggungjawab.

\section{Daftar Rujukan}

Dahliyana, Asep. 2017. Penguatan Pendidikan Karakter Melalui Kegiatan Ekstrakurikuler Di Sekolah. Sosio Religi Jurnal Pendidikan Umum/Nilai. 15(1).

Djojonegoro, Wardiman. (1998). Pengembangan Sumberdaya melalui Sekolah Menengah Kejuruan (SMK). Jakarta: Jayakarta Agung Offset.

Hidrawati, 2017. Sosialitas. Jurnal Ilmiah Pend. Sos Ant. Jenkins, Richard. 2016. Membaca Pikiran Pierre Bourdieu. Bantul. Kreasi Wacana offset 
Kementerian Pendidikan Nasional, Badan penelitian dan pengembangan, Pusat kurikulum. 2011, Pengembangan Pendidikan Budaya Dan Karakter Bangsa Pedoman Sekolah. Jakarta: Pusat Kurikulum.

Rachman, Maman dan Lestari, Puji. 2017. Pendidikan dan Pembinaan Karakter Bangsa. Semarang: Fastindo.

Tirtoni, Fery. 2016. Pembelajaran PKn di SD Inovasi melalui Strategi Habituasi dan Program Kegiatan Sekolah Berkarakter.Yogyakarta: CV. Buku Baik

Wuryadani, Wuri. Fathurrohman. Ambarwati, Unik. 2016. Implementasi Pendidikan Karakter Kemandirian Di Muhammadiyah Boarding School. Cakrawala Pendidikan.

UU No. 20 tahun 2003 tentang Sistem Pendidikan Nasional 